\title{
Gut Pathogens: enteric health at the interface of changing microbiology
}

\author{
Niyaz Ahmed ${ }^{* 1}$, Leonardo A Sechi², Francis Megraud ${ }^{3}$ and Seyed E Hasnain ${ }^{4}$
}

Address: ${ }^{1}$ Pathogen Biology Laboratory, Department of Biotechnology, University of Hyderabad, Hyderabad, India, ${ }^{2}$ Department of Biomedical Sciences, University of Sassari, Sassari, Italy, ${ }^{3}$ INSERM - U853, Laboratoire de Bactériologie, CHU Pellegrin, 33076 Bordeaux cedex, France and ${ }^{4}$ Institute of Life Sciences, Hyderabad University Campus, Hyderabad, India

Email: Niyaz Ahmed* - ahmed.nizi@gmail.com; Leonardo A Sechi - sechila@uniss.it; Francis Megraud - francis.megraud@chu-bordeaux.fr; Seyed E Hasnain - hs_ehtesham@hotmail.com

* Corresponding author

Published: 3 February 2009

Gut Pathogens 2009, I:I doi:10.1 186/1757-4749-I-1

This article is available from: http://www.gutpathogens.com/content/l/I/I

This is an Open Access article distributed under the terms of the Creative Commons Attribution License (http://creativecommons.org/licenses/by/2.0), which permits unrestricted use, distribution, and reproduction in any medium, provided the original work is properly cited.

As the open access movement begins revolutionizing the publication of publicly funded biomedical research, it is time to ensure access to important scientific discoveries and opinions within and across the disciplines which have direct bearing on health and quality of life in resource poor settings and in countries of the world where library budgets are seriously shrinking. In this concern, the area of enteric infectious diseases and gut health has been of paramount significance. For example, the enteric infections that cause diarrhoeal diseases already constitute one of the top 10 causes of death and kill approximately 1.81 million people in the developing world (6.9\% of total deaths), a figure which is more dramatic and alarming than the number of deaths associated with tuberculosis and malaria put together (Source: The WHO) [1].

To this end, the International Society for Genomic and Evolutionary Microbiology (ISOGEM) in collaboration with BioMed Central Ltd. has launched Gut Pathogens with the aim of providing a high-quality forum for research on enteric infections of humans and animals. The journal led by three Editors-in-Chief and supported by a highly qualified and organized international Editorial Board [2] publishes open access research articles of repute in areas of biology and the pathogenesis of bacterial, parasitic and viral infections of the gut including their diagnosis, epidemiology and clinical management.
Received: 28 January 2009

Accepted: 3 February 2009
Besides publication of peer-reviewed research articles and case reports, Gut Pathogens is also mandated to publish scholarly reviews and other opinionated articles related to microbial etiology of gut ailments; microbial invasion mechanisms; bacterial toxins and virulence factors of the pathogens of gut and associated glands (liver, pancreas); bacterial adaptation and evolution of pathogenicity; molecular and serological diagnoses; treatment, vaccines and antimicrobial resistance mechanisms; molecular epidemiology, transmission dynamics and evolutionary genetics and comparative and veterinary infectious diseases of the gut.

The field of medical microbiology has expanded tremendously in the aftermath of genomic revolution [3], and microbial organisms in the gut have already taken center stage among all other microbiota of the human surfaces [4-6]. Metagenomics and systems biology approaches $[4,5]$ have enabled new insights [6] into the complex existence of the gut ecosystem and hold tremendous potential to boost our understanding of the elements of host-microbial co-evolution, commensalism versus parasitic invasions and the boundaries thereof. In view of such an exciting and fast-moving scenario, there is a clear opportunity for Gut Pathogens to be seen also as a timely initiative to serve communities associated with a) biology and ecology of gut pathogens, the commensals and the probiotic species $[7,8]$ in health and disease, b) host susceptibility or resistance to such organisms, c) immune reactions of gut infections and d) the triggers of autoim- 
munity in inflammatory bowel diseases $[9,10]$ and other metabolic syndromes $[11,12]$.

As like all BioMed Central journals, Gut Pathogens shall be committed to the open access publication policy - the concept that has revolutionized research access to communities and that was recently endorsed by major funding agencies including the NIH and the Wellcome Trust. In addition to its embracement of open access, Gut Pathogens shall also aim to support the concept of Science 2.0 [13] by providing a truly open platform for discussions, commenting and rating of the subjective impact of individual articles.

In the near future, medical and biosciences communities will need to possibly consider novel findings and paradigms that are emerging in the aftermath of genome sequencing and metagenomics of the gut microorganisms. Also, those who diagnose and treat patients with enteric disorders will need to understand the nature and complexities of the interactions of the so called 'invaders' [14] with our intestinal ecosystem in health, and their perturbations in disease, and the roles and contribution of our gut symbionts and commensals in guarding and ensuring normalcy of the gut or otherwise. This shall greatly facilitate the practice of preventive and social medicine in a most effective and pertinent manner. Gut Pathogens will always strive to assist scientists and clinicians in this endeavor by translating the most recent advances for the benefit of patients.

\section{References}

I. The Top 10 causes of death [http://www.who.int/mediacentre/ factsheets/fs $310 /$ en/index.html]

2. Gut Pathogens Editorial Board [http://www.gutpathogens.com/ edboard/]

3. Ahmed N, Dobrindt U, Hacker J, Hasnain SE: Genomic fluidity and pathogenic bacteria: applications in diagnostics, epidemiology and intervention. Nat Rev Microbiol 2008, 6:387-94.

4. Jacobs DM, Gaudier E, van Duynhoven J, Vaughan EE: Non-digestible food ingredients, colonic microbiota and the impact on gut health and immunity: a role for metabolomics. Curr Drug Metab 2009, 10:41-54.

5. Turnbaugh PJ, Gordon Jl: An invitation to the marriage of metagenomics and metabolomics. Cell 2008, 134:708-13.

6. Turnbaugh PJ, Hamady M, Yatsunenko T, Cantarel BL, Duncan A, Ley RE, Sogin ML, Jones WJ, Roe BA, Affourtit JP, Egholm M, Henrissat B, Heath AC, Knight R, Gordon Jl: A core gut microbiome in obese and lean twins. Nature 2008, 457:480-84.

7. Collado MC, Isolauri E, Salminen S, Sanz Y: The impact of probiotic on gut health. Curr Drug Metab 2009, 10:68-78.

8. Bodera P, Chcialowski A: Immunomodulatory effect of probiotic bacteria. Recent Pat Inflamm Allergy Drug Discov 2009, 3:58-64.

9. Scanu AM, Bull TJ, Cannas S, Sanderson JD, Sechi LA, Dettori G, Zanetti $S$, Hermon-Taylor J: Mycobacterium avium subspecies paratuberculosis infection in cases of irritable bowel syndrome and comparison with Crohn's disease and Johne's disease: common neural and immune pathogenicities. J Clin Microbiol 2007, 45:3883-90.

10. Sechi LA, Gazouli M, Sieswerda LE, Molicotti P, Ahmed N, Ikonomopoulos J, Scanu AM, Paccagnini D, Zanetti S: Relationship between Crohn's disease, infection with Mycobacterium avium subspecies paratuberculosis and SLCIIAI gene poly- morphisms in Sardinian patients. World J Gastroenterol 2006, 1 2:716|-4.

II. Sechi LA, Paccagnini D, Salza S, Pacifico A, Ahmed N, Zanetti S: Mycobacterium avium subspecies paratuberculosis bacteremia in type-I diabetes mellitus: an infectious trigger? Clin Infect Dis 2008, 46: I48-9.

12. Sechi LA, Rosu V, Pacifico A, Fadda G, Ahmed N, Zanetti S: Humoral immune responses of type I diabetes patients to Mycobacterium avium subsp. paratuberculosis lend support to the infectious trigger hypothesis. Clin Vaccine Immunol 2008, 15:320-6.

13. Science 2.0 - Is Open Access Science the Future? [http:// www.sciam.com/article.cfm? id=science-2-point-0]

14. Hermon-Taylor J: Gut Pathogens: Invaders and turncoats in a complex cosmos. Gut Path 2009, I:3.
Publish with BioMed Central and every scientist can read your work free of charge

"BioMed Central will be the most significant development for disseminating the results of biomedical research in our lifetime. "

Sir Paul Nurse, Cancer Research UK

Your research papers will be:

- available free of charge to the entire biomedical community

- peer reviewed and published immediately upon acceptance

- cited in PubMed and archived on PubMed Central

- yours - you keep the copyright 